\title{
Unearthing of Radioisotopes
}

\section{Nida Tabassum Khan*}

Department of Biotechnology, Faculty of Life Sciences and Informatics, Balochistan University of Information Technology Engineering and Management Sciences (BUITEMS), Quetta, Pakistan

"Corresponding author: Tabassum Khan N, Department of Biotechnology, Faculty of Life Sciences and Informatics, Balochistan University of Information Technology Engineering and Management Sciences (BUITEMS), Quetta, Pakistan, Tel: +92 3368164903; E-mail: idatabassumkhan@yahoo.com

Received: July 25, 2017; Accepted: August 12, 2017; Published: August 21, 2017

Copyright: (c) 2017 Tabassum Khan N. This is an open-access article distributed under the terms of the Creative Commons Attribution License, which permits unrestricted use, distribution, and reproduction in any medium, provided the original author and source are credited.

\section{Abstract \\ Isotopes were discovered by Frederick Soddy which are the different forms of the same elements that differs in their number of neutrons and also possess radioactive properties. These isotopes are relatively stable and could be used for numerous purposes.}

Keywords: Neutrons; Radioactive; Atomic number; Atomic mass

\section{Introduction}

Discovery of isotopes began when evidences were gathered to reveal that some element possess radioactive properties. In 1910, it was observed that certain elements transformed from their unstable state to a highly stable state following the emission of radiations that were found to be radioactive. Salts of thorium and uranium were identified as radioactive. Ionium was produced by uranium ores while mesothorium was yielded by thorium ores which gave these elements their recognized names. Since ionium when mixed with thorium could not be restored by chemicals routes. Likewise, mesothorium was found to be chemically similar to radium. So, it was concluded that ionium and mesothorium were different forms of their corresponding existing elements. Such elements were termed as "Isotopes" by Frederick Soddy who won a Nobel Prize in 1921 for his tremendous work [1]. Isotope is defined as the form of the same elements with different number of neutrons. It means they differs in their atomic masses but have similar atomic number therefore occupy the same position in the periodic table. He also revealed uranium and thorium decay into different isotopes of lead. Since lead was discovered from uranium and thorium rich ores with different atomic masses of 206.08 and 207.69 respectively [2-4]. There are numerous stable isotopes of different element with varying relative abundance given below in Table 1 [5-9].

\begin{tabular}{|c|c|c|}
\hline Isotope & Rel. Abundance & Half-life (years) \\
\hline Holmium-166 m & - & 1,200 \\
\hline Berkelium-247 & - & 1,380 \\
\hline Radium-226 & Trace & 1,600 \\
\hline Molybdenum-93 & - & 4,000 \\
\hline Holmium-153 & - & 4,570 \\
\hline Curium-246 & - & 4,730 \\
\hline Carbon-14 & Trace & 5,730 \\
\hline Plutonium-240 & - & 6,563 \\
\hline Thorium-229 & - & 7,340 \\
\hline Americium-243 & - & 7,370 \\
\hline Curium-245 & - & 8,500 \\
\hline Curium-250 & - & 9,000 \\
\hline Tin-126 & - & 10,000 \\
\hline lodine-129 & - & 15,700 \\
\hline Niobium-94 & - & 20,300 \\
\hline
\end{tabular}




\begin{tabular}{|c|c|c|}
\hline Plutonium-239 & - & 24,110 \\
\hline Proactinium-231 & Trace & 32,760 \\
\hline Lead-202 & - & 52,500 \\
\hline Lanthanium-137 & - & 60,000 \\
\hline Thorium-230 & - & 75,380 \\
\hline Nickel-59 & - & 76,000 \\
\hline Thorium-230 & Trace & 77,000 \\
\hline Calcium-41 & - & 103,000 \\
\hline Neptunium-236 & - & 154,000 \\
\hline Uranium-233 & - & 159,200 \\
\hline Rhenium-186 m & - & 200,000 \\
\hline Technetium-99 & - & 211,000 \\
\hline Krypton-81 & - & 229,000 \\
\hline Uranium-234 & Trace & 245,500 \\
\hline Chlorine-36 & - & 301,000 \\
\hline Curium-248 & - & 340,000 \\
\hline Bismuth-208 & - & 368,000 \\
\hline Plutonium-242 & - & 373,300 \\
\hline Aluminum-26 & - & 717,000 \\
\hline Selenium-79 & - & $1,130,000$ \\
\hline Iron-60 & - & $1,500,000$ \\
\hline Beryllium-10 & - & $1,510,000$ \\
\hline Zircon-93 & - & $1,530,000$ \\
\hline Curium-247 & - & $1,560,000$ \\
\hline Gadolinium-150 & - & $1,790,000$ \\
\hline Neptunium-237 & - & $2,144,000$ \\
\hline Cesium-135 & - & $2,300,000$ \\
\hline Technetium-96 & - & $2,600,000$ \\
\hline Dysprosium-154 & - & $3,000,000$ \\
\hline Bismuth-310m & - & $3,040,000$ \\
\hline Mietnerium-53 & - & $3,740,000$ \\
\hline Technetium-98 & - & $4,200,000$ \\
\hline Lead-205 & - & $15,300,000$ \\
\hline Hafnium-182 & - & $9,000,000$ \\
\hline Palladium-107 & - & $6,500,000$ \\
\hline Curium-247 & Abundant & $15,600,000$ \\
\hline
\end{tabular}




\begin{tabular}{|c|c|c|}
\hline Uranium-236 & - & $23,420,000$ \\
\hline Niobium-92 & - & $34,700,000$ \\
\hline Plutonium-244 & - & $80,800,000$ \\
\hline Samarium-146 & - & $103,000,000$ \\
\hline Uranium-236 & - & $234,200,000$ \\
\hline Uranium-235 & Rare & $703,800,000$ \\
\hline Potassium-40 & Rare & $1,280,000,000$ \\
\hline Uranium-238 & Abundant & $4,468,000,000$ \\
\hline Rubidium-87 & Abundant & $4,750,000,000$ \\
\hline Thorium-232 & Abundant & $14,100,000,000$ \\
\hline Lutetium-176 & Rare & $37,800,000,000$ \\
\hline Rhenium-187 & Abundant & $43,500,000,000$ \\
\hline Lanthanium-138 & Rare & $105,000,000,000$ \\
\hline Samarium-147 & Abundant & $106,000,000,000$ \\
\hline Platinum-190 & Rare & $650,000,000,000$ \\
\hline Tellurium-123 & Rare & $>1 \times 10^{13}$ \\
\hline Osmium-184 & Rare & $>5.6 \times 10^{13}$ \\
\hline Gadolinium-152 & Rare & $1.08 \times 10^{14}$ \\
\hline Tantalum-180 m & Rare & $>1.2 \times 10^{15}$ \\
\hline Xenon-124 & Rare & $>1.6 \times 10^{14}$ \\
\hline Indium-115 & Abundant & $4.41 \times 10^{14}$ \\
\hline Zinc-70 & Rare & $>5 \times 10^{14}$ \\
\hline Hafnium-174 & Rare & $2.0 \times 10^{15}$ \\
\hline Osmium-186 & Abundant & $2.0 \times 10^{15}$ \\
\hline Samarium-149 & Abundant & $>2 \times 10^{15}$ \\
\hline Neodymium-144 & Abundant & $2.29 \times 10^{15}$ \\
\hline Samarium-148 & Abundant & $7 \times 10^{15}$ \\
\hline Cadmium-113 & Abundant & $7.7 \times 10^{15}$ \\
\hline Cerium-142 & Abundant & $>5 \times 10^{16}$ \\
\hline Tungsten-183 & Abundant & $>1.1 \times 10^{17}$ \\
\hline Vanadium-50 & Rare & $1.4 \times 10^{17}$ \\
\hline Lead-204 & Abundant & $1.4 \times 10^{17}$ \\
\hline Chromium-50 & Abundant & $>1.8 \times 10^{17}$ \\
\hline Tungsten-184 & Abundant & $>3 \times 10^{17}$ \\
\hline Calcium-48 & Abundant & $>6.3 \times 10^{18}$ \\
\hline Molybdenum-100 & Abundant & $1.0 \times 10^{19}$ \\
\hline
\end{tabular}




\begin{tabular}{|l|l|l|}
\hline Neodynium-150 & Abundant & $>1.1 \times 10^{19}$ \\
\hline Zircon-96 & Abundant & $>3.8 \times 10^{19}$ \\
\hline Selenium-82 & Abundant & $1.1 \times 10^{20}$ \\
\hline Tellurium-130 & Abundant & $7.9 \times 10^{20}$ \\
\hline Xenon-136 & Abundant & $>2.4 \times 10^{21}$ \\
\hline Tellurium-128 & Abundant & $2.2 \times 10^{24}$ \\
\hline
\end{tabular}

Table 1: List of Isotopes.

These stable isotopes of different elements have a wide range of applications in different research areas some of their applications are stated below in Table 2 [10-20].

\begin{tabular}{|c|c|}
\hline Isotopes & Uses \\
\hline Thorium-230 & Coloring and fluorescent agent in glassware and colored glazes \\
\hline Californium-252 & Explosives detection, monitor soil moisture content and the moisture of materials stored in soils \\
\hline Krypton-85 & $\begin{array}{l}\text { Monitors thickness of thin plastics, metal sheet, rubber, textiles and paper. Pollutant indicator. Used in indicator lights in different } \\
\text { electronic appliances. }\end{array}$ \\
\hline Carbon-14 & Biological tracer for pharmacological studies. \\
\hline Cesium-137 & Chemotherapy of cancers and tumors, measurement of correct radio medicine, monitoring and controlling fluid flow in pipelines etc. \\
\hline Americum-241 & smoke detectors, measure levels of toxic lead in dried paint samples \\
\hline Tritium (H3) & Geological mining, hydrology, used in luminous paint \\
\hline Iron-55 & Electroplating solutions analysis, detection of sulphur in air, metabolic pathway studies. \\
\hline Cobalt-60 & Surgical instruments sterilization, cancer treatment, food irradiation and radiography. \\
\hline Thoriated Tungsten & Used in welding, aircraft, petrochemical and food processing equipment industries. \\
\hline Uranium-235 & Nuclear fuel for power plants and naval nuclear propulsion \\
\hline Cadmium-109 & Analyzing metal alloys, scrap sorting \\
\hline Sodium-24 & Detection of oil leakages in industrial pipelines \\
\hline Plutonium-238 & Has powered more than 20 NASA spacecrafts since 1972 \\
\hline Nickel-63 & Explosives detection, voltage regulators, current flow protectors in electronic devices. \\
\hline Thallium-204 & Detect and quantifies pollutant levels and measures the thickness of plastics, sheet metal, rubber, textiles, and paper. \\
\hline Promethium-147 & Used in electric blanket thermostats \\
\hline Sulphur-35 & Used in survey meters in case of emergencies \\
\hline Curium-244 & Geological mining to analyze material unearthed from pits and slurries from drilling operations \\
\hline Polonium-210 & Reduction of static charge in production of photographic film \\
\hline Sulphur-35 & Used in survey, cigarette manufacturing sensors and medical therapies. \\
\hline Iridium-192 & Used to test the integrity of pipeline welds, boilers and aircraft parts and in brachy therapy/tumor irradiation. \\
\hline Radium-226 & Makes lighting rods more effective. \\
\hline
\end{tabular}


Table 2: Applications of Isotopes.

\section{Suppliers of radioisotopes}

The main world isotope suppliers are as follows:

ANSTO in Australia,

BR-2 at Mol in Belgium,

Dimitrovgrad in Russia,

ETRR-2 in Egypt,

FRJ-2/ FRM-2 at Julich in Germany,

HFETR at Chengdu in China,

HFR at Petten in Netherlands,

IRE in Europe,

Isotope-NIIAR in Russia,

LWR-15 at Rez in Czech Republic,

Mallinckrodt Pharmaceuticals in Ireland,

Maria in Poland,

MDS Nordion in Canada,

NRU at Chalk River in Canada,

NTP in South Africa,

OPAL in Australia

Osiris \& Orphee at Saclay in France,

Safari in South Africa [21-24].

\section{Conclusion}

So, it was concluded that discovery of different isotopes of different elements could offer numerous biological and chemical applications used for the welfare of mankind.

\section{References}

1. Soddy F (1922) The origins of the conceptions of isotopes. Nobel lecture.

2. Frondel C (1958) Systematic mineralogy of uranium and thorium. US Government Printing Office.
3. Nystrom A, Parker A, Thoennessen M (2010) Discovery of Isotopes. In APS Division of Nuclear Physics Meeting.

4. Romer A (1970) Radiochemistry and the Discovery of Isotopes.

5. Firestone RB, Shirley VS (1998) Table of isotopes. 2 volume set; Table of Isotopes, 2 Volume Set, p: 3168.

6. Lederer CM, Hollander JM, Perlman I (1967) Table of isotopes.

7. Hollander JM, Perlman I, Seaborg GT (1953) Table of isotopes. Rev Mod Phy 25: 469.

8. Browne E, Dairiki JM, Doebler RE (1978) Table of isotopes. National Standard Reference Data System.

9. Seaborg GT, Perlman I (1948) Table of isotopes. Rev Mod Phy 20: 585.

10. De Groot PA (2004) Handbook of stable isotope analytical techniques.

11. Faure G, Mensing TM (2005) Isotopes: principles and applications. John Wiley and Sons Inc.

12. Haskins NJ (1982) The application of stable isotopes in biomedical research. Biol Mass Spectro 9: 269-277.

13. Baillie TA (1978) Stable isotopes: Applications in Pharmacology. Toxicology and Clinical Research, Springer, Macmillan Press, London.

14. Hawkesworth CJ, Van Calsteren PWC (1984) Radiogenic isotopes-some geological applications. Rare Earth Elem Geochem 2: 375-442.

15. Smithers DW (1951) Some varied applications of radioactive isotopes to the localisation and treatment of tumours. Acta Radiologica 1: 49-61.

16. Lawrence JH, Tobias CA (1956) Radioactive isotopes and nuclear radiations in the treatment of cancer. Canc Res 16: 185-193.

17. Mayneord WV (1952) The radiography of the human body with radioactive isotopes. The British J Radiol 25: 517-525.

18. Vértes A, Nagy S, Klencsár Z, Lovas RG, Rösch F (2010) Handbook of Nuclear Chemistry. Springer Sci and Busin Media.

19. Low-Beer BV (1950) The clinical use of radioactive isotopes.

20. Beierwaltes WH, Johnson PC, Solari AJ (1957) Clinical use of radioisotopes. WB Saunders Company.

21. Richards P (1965) Nuclide generators. Brookhaven National Laboratory (BNL), Upton, NY, United States.

22. US Atomic Energy Commission. List of Commercial Suppliers of Radioisotopes, Current listing available from the USAEC, Division of Isotopes Development, $1717 \mathrm{H}$ Street.

23. Malcolme-Lawes DJ (1979) Sources of Radioisotopes. Introduction to Radiochemistry. Macmillan Education UK, pp: 12-19.

24. Sheard H (1963) International directory of radioisotopes: IAEA, p: 697. 